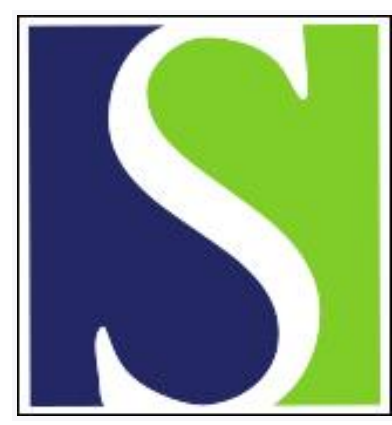

Scand J Work Environ Health 1988;14(5):286-292

https://doi.org/10.5271/sjweh.1918

Issue date: Oct 1988

Indoor radon exposure and active and passive smoking in relation to the occurrence of lung cancer.

by Axelson O, Andersson K, Desai G, Fagerlund I, Jansson B, Karlsson C, Wingren $\mathrm{G}$

Affiliation: Department of Occupational Medicine, University Hospital, Linkoping, Sweden.

This article in PubMed: www.ncbi.nlm.nih.gov/pubmed/3201187

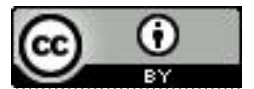




\title{
Indoor radon exposure and active and passive smoking in relation to the occurrence of lung cancer
}

\author{
by Olav Axelson, MD, ${ }^{1}$ Kjell Andersson, MD, ${ }^{2}$ Gunilla Desai, BA, ${ }^{1}$ Inger Fagerlund, ${ }^{2}$ \\ Bjarne Jansson, DrMedSci, ${ }^{3}$ Carina Karlsson, ${ }^{3}$ Gun Wingren, BA ${ }^{1}$
}

\begin{abstract}
AXELSON O, ANDERSSON K, DESAI G, FAGERLUND I, JANSSON B, KARLSSON C, WINGREN $G$. Indoor radon exposure and active and passive smoking in relation to the occurrence of lung cancer. Scand J Work Environ Health 14 (1988) 286-292. Exposure to indoor radon and radon daughters is currently attracting great interest as a possible cause of lung cancer. This concern is supported by several studies, most of them relatively small in numbers or weak in the assessment of exposure. This study encompasses 177 persons with lung cancer and 677 noncancer referents, all deceased and with 30 years or more of residency in the same house in an area with radon-leaking alum shale deposits in the central part of southern Sweden. Exposure categories based on building material, type of house, and ground conditions were created, but measurements of the indoor radon daughter concentration were also made for 142 cases and 264 referents. Active and passive smoking was ascertained through questionnaires sent to the next-of-kin. Overall, the lung cancer risk was approximately twofold with regard to the categories of assumed radon daughter exposure for the rural sector of the population but not for the same categories of the urban sector, possibly because of less precise exposure assessment and influence from other factors. Occasional and passive smokers, as well as passive smokers alone, had a particularly increased risk of lung cancer in association with the increased exposure categories.
\end{abstract}

Key terms: alum shale, case-referent study, dwellings, epidemiology, ground radiation, homes.

Since the late 1970s, several epidemiologic studies have been undertaken to evaluate the possible role of indoor radon in the lung cancer risk of the general population. Most of these studies have been of the casereferent type $(3,4,8,11,16,17,23,25)$, but there has also been an attempt to use a cohort design (24). Several correlation studies have been published regarding the occurrence of lung cancer in various administrative or geographic regions in relation to estimated background radiation, the estimates being also considered as indicative of radon concentrations in homes $(6,9$, $10,12,13,14,15$ ).

The main problem in studies of indoor radon and lung cancer is the assessment of exposure to radon and its decay products (the radon daughters), the latter being mainly responsible for the irradiation of the respiratory tract. The leakage of radon into homes depends on the building material and ground conditions. The emanation of radon from the ground may vary locally due to the type and porosity of the soil and the existence of cracks in the ground, and it can be more important than the contribution from various kinds of stony building materials (1). Furthermore, ventila-

\footnotetext{
1 Department of Occupational Medicine, University Hospital, Linköping, Sweden.

2 Department of Occupational Medicine, Section of Environmental Medicine, Örebro Medical Center Hospital, Örebro, Sweden.

3. Department of Preventive Medicine and Community Health, County Council of Skaraborg, Skövde, Sweden.
}

Reprint requests to: Professor O Axelson, Department of OCcupational Medicine, University Hospital, 58185 Linköping, Sweden. tion greatly affects the concentrations of radon and radon daughters that build up in a room. Therefore exposure levels vary over time due to behavioral factors influencing ventilation, and even extensive measurements undertaken in a number of houses (as subsequently occupied by an individual) would be an uncertain basis for assessing cumulative exposure over time. As a consequence, any estimation of individual exposure is likely to be imprecise, and this imprecision makes it difficult to create the contrasts in exposure needed to distinguish any difference in lung cancer morbidity in relation to radon and radon daughter exposure.

This study was restricted to an area with uraniumcontaining alum shale deposits in the central part of southern Sweden, where the radon emanation from the ground is relatively high. It was designed to reproduce the results of an earlier study from the island of Oeland on a larger scale (11). The geology of the study area is similar in character to that of the island. However, the alum shale of Oeland appears only in a narrow strip on the west side of the island and can thus be easily defined, whereas the geology of the areas involved in the present study is less distinct. Therefore it was somewhat more difficult in this study to separate houses likely to have had high levels of radon on a long-term basis from those with low levels.

\section{Subjects and methods}

Fourteen communes within the counties of Skaraborg, Örebro, and Östergötland were selected for study in 
the alum shale area. They represented both urban and rural conditions and contained a population of about 300000 , a large part of which was expected to have lived in houses with increased indoor levels of radon. In contrast to the populations of our earlier studies $(2,11)$ the population was urban as well as rural, and this urban contribution infers a greater potential for occupational lung cancer risk, which would blur a possible effect of radon daughter exposure. Furthermore, people in urban areas tend to spend considerable time in buildings other than their homes, and exposure to radon and radon daughters may also take place in these buildings, where there is also a possibility of exposure to environmental tobacco smoke and other carcinogens. Therefore, the assumptions about cumulative radon daughter exposure, either estimated in terms of exposure categories or based only on radon measurements in the homes, tend to become less certain with respect to actual long-term exposure.

\section{Selection of the subjects}

The national register of deaths was examined for all deaths from lung cancer [code $162-163$ of the International Classification of Diseases, eighth revision (ICD-8)] in the 14 communes for the period 19601981 , the result being the identification of 1087 lung cancer cases. From the same communes a fourfold larger sample of noncancer deaths (ie, 4348 deaths) was randomly drawn as the reference sample from the register without any geographic or other matching. However, due to insufficient funds, three communes had to be dropped from the study, the initial numbers thereby being immediately decreased by 225 cases and 1046 referents. A further reduction involved three persons with lung cancer and 33 referents because they were not found in the local registers or their period of residency was impossible to verify.

The age range of the subjects in the study was restricted to $30-84$ years, as there were no young cases and the diagnostic uncertainty was thought to increase considerably in the very high age range. To obtain as high a level of exposure control as possible with the limited funds available, we found it necessary to reduce the number of houses, especially with regard to the expensive measurements of indoor radon daughter concentrations. Therefore, the subjects were also restricted to individuals who had lived at the same address for at least 30 years prior to death, and this restriction resulted in the exclusion of 676 cases and 2579 referents. All the houses occupied by the remaining subjects were visited and classified as described in the next section. However, certain characteristics (building material or basement) of the houses of six cases and 17 referents could not be ascertained.

Finally, 177 cases and 673 referents (ie, 20.5 and $20.3 \%$, respectively, of the initial groups from the 11 communes) remained. For these subjects, the information obtained about potential exposure to radon and its decay products was reasonably complete.

\section{Assessment of exposure and smoking habits}

The addresses of the cases and referents were obtained through the local population registers, and the houses were then located on large-scale economic maps. This procedure permitted the geographic identification of each individual house.

The assessment of exposure was then made in two ways. First, all of the houses were classified on the basis of a visual inspection. Then, measurements of radon daughters were made in all of the available houses of the cases, and a random sampling was made of the houses of the referents, again a restriction necessary for economic reasons. A commercially processed alpha-sensitive Kodak film was used for these measurements, and each houseowner was sent two strips of film by letter. The exposure time of the film was two months, and both the summer and the winter months were avoided. Only houses with permanent residence could be measured for practical reasons. A few of these houses had already been measured by the local health authorities, and no new measurements were undertaken in these dwellings. Measurements were made in the houses of 142 cases and 264 referents.

For the ocular classification of the houses with regard to potential exposure of the subjects, each house was visited, and, as judged from the outside, the building material and type of house were registered. This classification was undertaken without knowledge of whether a person with lung cancer or a referent had lived in the house.

The houseowner also filled out a questionnaire in connection with the measurements, and, if other construction of the house was reported with regard to the basement, building material, etc; the ocular classification was adjusted according to this information. Georadiation maps (Sveriges Geologiska Undersökning, Uppsala 1980) were used to determine if a house was situated on ground with increased radiation (ie, exceeding $2.15 \times 10^{-12} \mathrm{Akg}^{-1}$ or $30 \mu \mathrm{R} / \mathrm{h}$ ). On the average, such "radiation" ground is known to leak radon more than "normal" ground.

Thereafter, three exposure categories were used exactly as in a previous study (11), the reference (category $0)$ being wooden houses without a basement on normal ground and category 2 being wooden houses with a basement on radiation ground (the alum shale zone) or stone, brick and plaster houses with a basement on any ground, alternatively without a basement on radiation ground. All other types of houses were classed as exposure category 1 (ie, also wooden houses without a basement but on radiation ground). However, an alternative, simple exposure classification was also established with regard to the wall material of the houses.

Information on the smoking habits of the subjects, including passive smoking, was obtained primarily from a questionnaire filled out by the next-of-kin but also sometimes from information obtained from the present houseowner. Information on smoking habits was available for 152 of the cases and 457 of the refer- 
ents whose houses had also been categorized. Of these 152 cases and 457 referents, 128 and 242 , respectively, had also had exposure measurements made.

\section{Statistical methods}

The calculation of chi-square values and the estimation of the overall odds ratios, equaling the incidence density ratios with the applied design (2), were based on the Mantel-Haenszel procedure (19). Trends were tested by the Mantel extension of the Mantel-Haenszel test, and the exposure categories were scored as $\mathbf{0 , 1}$, and 2 (18). The principles applied for determining the

Table 1. Measured radon daughter concentrations in houses according to exposure category, wall material, and type of ground with regard to radiation.

\begin{tabular}{|c|c|c|c|}
\hline & \multicolumn{3}{|c|}{$\begin{array}{l}\text { Radon daughter concentrations } \\
\left(\mathrm{Bq}^{\prime} \mathrm{m}^{3} \mathrm{EER}\right)\end{array}$} \\
\hline & $\begin{array}{c}\text { Number } \\
\text { of houses }\end{array}$ & Mean & $S D^{b}$ \\
\hline \multicolumn{4}{|l|}{ Exposure category ${ }^{c}$} \\
\hline $\begin{array}{l}0 \\
1 \\
2\end{array}$ & $\begin{array}{r}99 \\
155 \\
152\end{array}$ & $\begin{array}{r}56.8 \\
96.6 \\
112.3\end{array}$ & $\begin{array}{r}52.2 \\
292.9 \\
316.9\end{array}$ \\
\hline \multicolumn{4}{|l|}{ Wall material } \\
\hline $\begin{array}{l}\text { A. Wood } \\
\text { B. Stone, brick, or other } \\
\text { C. Lightweight alum shale }\end{array}$ & $\begin{array}{r}292 \\
77\end{array}$ & $\begin{array}{r}96.1 \\
52.3\end{array}$ & $\begin{array}{r}298.1 \\
60.5\end{array}$ \\
\hline $\begin{array}{l}\text { concrete } \\
\text { D. Possibly lightweight } \\
\text { alum shale concrete } \\
\text { E. Mixed materials }\end{array}$ & $\begin{array}{r}12 \\
19 \\
6\end{array}$ & $\begin{array}{l}123.8 \\
162.1 \\
169.2\end{array}$ & $\begin{array}{l}113.6 \\
312.9 \\
324.1\end{array}$ \\
\hline $\begin{array}{l}A+B \\
C+D+E\end{array}$ & $\begin{array}{l}304 \\
102\end{array}$ & $\begin{array}{r}87.0 \\
150.8\end{array}$ & $\begin{array}{l}167.1 \\
260.5\end{array}$ \\
\hline \multicolumn{4}{|l|}{ Ground } \\
\hline $\begin{array}{l}\text { Normal } \\
\text { Radiation }\end{array}$ & $\begin{array}{l}246 \\
160\end{array}$ & $\begin{array}{r}55.5 \\
150.0\end{array}$ & $\begin{array}{r}58.1 \\
413.2\end{array}$ \\
\hline
\end{tabular}

a EER = equilibrium equivalent radon according the International Commission on Radiation Protection (publication 24, 1976).

- Values similar to, or greater than, the mean are formally reported as showing that the distribution was highly skewed.

c $0=$ reference, ie, wooden houses without a basement on normal ground, $1=$ all types of houses not classed as 0 or 2, 2 = wooden houses with a basement on radiation ground or stone, brick and plaster houses with a basement on any ground, alternatively without a basement on radiation ground.

Table 2. Lung cancer cases and the referents according to the exposure categories and sex. The study period was 19601981.

\begin{tabular}{lrrrr}
\hline \multirow{4}{*}{ Sex } & \multicolumn{4}{c}{ Exposure category } \\
\cline { 2 - 5 } & 0 & 1 & 2 & $1+2$ \\
\hline Male & & & & \\
$\quad$ Cases & 27 & 46 & 52 & 98 \\
$\quad \begin{array}{l}\text { Referents } \\
\text { Female }\end{array}$ & 120 & 131 & 128 & 259 \\
$\quad$ Cases & & & & \\
$\quad$ Referents & 16 & 16 & 20 & 36 \\
\hline Total & 113 & 93 & 88 & 181 \\
$\quad$ Cases & & & & \\
$\quad$ Referents & 43 & 62 & 72 & 134 \\
\hline Crude rate ratio & 233 & 224 & 216 & 440 \\
\hline Mantel-Haenszel rate ratio & 1.0 & 1.5 & 1.8 & 1.7 \\
90 \% confidence interval & 1.0 & 1.4 & 1.7 & 1.6 \\
Mantel extension chi-square: 6.33 & & & \\
\hline
\end{tabular}

a See footnote $c$ of table 1 for an explanation of the exposure categories. standardized rate ratios have been outlined by Miettinen $(20,21)$, together with the method used for calculating the approximate (test-based) $90 \%$ confidence interval $(90 \% \mathrm{CI})$ of the rate ratios (22). A logistic regression analysis of the material was also undertaken, but its results have not been reported since they did not differ essentially from those of the stratified analyses.

\section{Results}

Table 1 shows the average radon daughter concentrations for the exposure categories according to the wall material in those houses that were measured. It can also been seen that the influence of the type of ground on the indoor radon daughter levels was considerable.

Table 2 shows the 177 cases and 673 referents in the study with regard to the exposure categories, the Mantel-Haenszel estimates being 1.0, 1.4, and $\mathbf{1 . 7}$ for the three categories 0,1 , and 2 , respectively (chi-square for trend $=6.33 ; \mathrm{P}=0.006$, one-tailed). An analysis with regard to normal and radiation ground showed a rate ratio for the latter category of only 0.9 , however. The smoking status of the subjects in the three exposure categories and the assumed radon daughter exposure of the cases and referents appear in table 3 for the rural population and in table 4 for the urban population. Somewhat surprisingly there were opposite patterns for the rate ratios with regard to the exposure categories. If these two tables are merged and the stratification maintained, the corresponding MantelHaenszel rate ratios are 1.0, $1.2(90 \% \mathrm{Cr} 0.7-1.8)$, and $1.2(90 \% \mathrm{CI} 0.7-2.0)$ for exposure categories 0 , 1 , and 2 , respectively.

Table 3 reveals a relatively clear dose-response relationship for the nonsmokers and passive and occasional smokers in the rural population (chi-square for trend $=5.38 ; \mathrm{P}=0.01$, one-tailed); in this analysis, those subjects with little or no exposure to cigarette smoke were combined. Among the regular smokers there was no clear dose-response relationship, but there seemed to be a slightly elevated, although not significant, overall risk of lung cancer. The urban population showed a completely different pattern with a negative dose-response relationship (table 4). It should be noted however that the numbers in the reference category are small, either with regard to the number of cases or to the number of referents or to both, and therefore the estimates are unstable for all the categories. A further analysis showed that especially the subpopulation having lived in detached houses in the urban areas was mainly responsible for the absence of a dose-response pattern.

As appears in table 1, the simple classification according to the wall material only differentiated between the higher and lower levels of measured indoor radon daughter activity, and table 5 was constructed with regard to this alternative classification of exposure. The rate ratios seemed to follow the average levels of radon 
Table 3. Lung cancer cases and the referents in rural areas according to the exposure categories and smoking status. Stratification by age, sex, and smoking characteristics is not shown.

\begin{tabular}{|c|c|c|c|c|}
\hline \multirow{2}{*}{ Smoking status } & \multicolumn{4}{|c|}{ Exposure category ${ }^{a}$} \\
\hline & 0 & 1 & 2 & $1+2$ \\
\hline \multicolumn{5}{|c|}{$\begin{array}{l}\text { Nonsmokers, passive smokers and } \\
\text { occasional smokers combined }\end{array}$} \\
\hline $\begin{array}{l}\text { Cases } \\
\text { Referents }\end{array}$ & $\begin{array}{r}16 \\
124\end{array}$ & $\begin{array}{r}15 \\
87\end{array}$ & $\begin{array}{l}13 \\
38\end{array}$ & $\begin{array}{r}28 \\
125\end{array}$ \\
\hline Crude rate ratio & 1.0 & 1.3 & 2.7 & 1.7 \\
\hline $\begin{array}{l}\text { Mantel-Haenszel rate ratio } \\
90 \% \text { confidence interval }\end{array}$ & 1.0 & $0.7-2.6$ & $\stackrel{2.8}{1.4-5.7}$ & $1.0-3.3$ \\
\hline \multicolumn{5}{|c|}{ Mantel extension chi-square: 5.38} \\
\hline \multicolumn{5}{|l|}{ Regular smokers } \\
\hline $\begin{array}{l}\text { Cases } \\
\text { Referents }\end{array}$ & $\begin{array}{l}12 \\
16\end{array}$ & $\begin{array}{l}23 \\
20\end{array}$ & $\begin{array}{r}6 \\
11\end{array}$ & $\begin{array}{l}29 \\
31\end{array}$ \\
\hline Crude rate ratio & 1.0 & 1.5 & 0.7 & 1.3 \\
\hline $\begin{array}{l}\text { Mantel-Haenszel rate ratio } \\
90 \% \text { confidence interval }\end{array}$ & 1.0 & $0.7^{1.5}-3.4$ & $0.2-2.1$ & $\begin{array}{c}1.2 \\
0.6-2.7\end{array}$ \\
\hline Mantel extension chi-squar & & & & \\
\hline
\end{tabular}

a See footnote $c$ of table 1 for an explanation of the exposure categories.

Table 4. Lung cancer cases and the referents in urban areas according to the exposure categories and smoking status. Stratification by age, sex, and smoking characteristics is not shown.

\begin{tabular}{|c|c|c|c|c|}
\hline \multirow{2}{*}{ Smoking status } & \multicolumn{4}{|c|}{ Exposure categorya } \\
\hline & 0 & 1 & 2 & $1+2$ \\
\hline \multicolumn{5}{|c|}{$\begin{array}{l}\text { Nonsmokers, passive smokers and } \\
\text { occasional smokers combined }\end{array}$} \\
\hline $\begin{array}{l}\text { Cases } \\
\text { Referents }\end{array}$ & $\begin{array}{r}3 \\
13 \\
13\end{array}$ & $\begin{array}{r}8 \\
39 \\
\cdots \cdots\end{array}$ & $\begin{array}{r}7 \\
70 \\
70\end{array}$ & $\begin{array}{r}15 \\
109 \\
.10\end{array}$ \\
\hline Crude rate ratio & 1.0 & 0.9 & 0.4 & 0.6 \\
\hline $\begin{array}{l}\text { Mantel-Haenszel rate ratio } \\
90 \% \text { confidence interval }\end{array}$ & $\begin{array}{c}1.0 \\
\cdot\end{array}$ & $\begin{array}{c}1.2 \\
0.5-3.2 \\
\end{array}$ & $\begin{array}{c}0.2 \\
0.03-0.7\end{array}$ & $\begin{array}{ll}0.7 \\
0.3-2.1 \\
\end{array}$ \\
\hline \multicolumn{5}{|l|}{ Regular smokers } \\
\hline $\begin{array}{l}\text { Cases } \\
\text { Referents }\end{array}$ & $\begin{array}{l}4 \\
2\end{array}$ & $\begin{array}{l}12 \\
15\end{array}$ & $\begin{array}{l}33 \\
22\end{array}$ & $\begin{array}{l}45 \\
37\end{array}$ \\
\hline Crude rate ratio & 1.0 & 0.4 & 0.8 & 0.6 \\
\hline $\begin{array}{l}\text { Mantel-Haenszel rate ratio } \\
90 \% \text { confidence interval }\end{array}$ & 1.0 & $\begin{array}{c}0.2 \\
0.04-1.5\end{array}$ & $\begin{array}{c}0.7 \\
0.2-3.4\end{array}$ & $\begin{array}{c}0.5 \\
0.1-2.5\end{array}$ \\
\hline
\end{tabular}

a See footnote $\mathrm{c}$ of table 1 for an explanation of the exposure categories.

daughters for the groups of individuals who were likely to be more highly exposed, with a risk that was approximately twofold the risk of those with a lower exposure.

For the measured exposure categories, only a very weakly positive association was obtained for the rate ratios with increasing levels of radon daughter concentrations in the rural population (table 6). There was no such phenomenon for the urbanized population; rather a reversed trend was seen. However only cases appeared among the regular smokers in the highest exposure category $\left(>150 \mathrm{~Bq} / \mathrm{m}^{3} \mathrm{EER}\right)$ of both the rural and the urban populations (six and five cases, respectively).
Table 7 shows the effect of assumed radon daughter exposure with regard to passive and occasional smoking. The merging of these smoking categories involves the idea that the occasional smoker is also likely to be more tolerant of the smoking of others, and their passive smoking might be more relevant in this context than the limited exposure from their own smoking. There were increasingly elevated rate ratios with assumed exposure for the respective categories and a slightly steeper trend in the Mantel-Haenszel rate ratios. For passive smoking among the women only, the Mantel-Haenszel rate ratios were 1.0, $1.5(90 \%$ CI $0.33-6.6)$, and $3.5(90 \%$ CI 1.0-11.2) for exposure categories 0,1 , and 2 , respectively. 
Table 5. Lung cancer cases and the referents according to the wall material classification of the houses and the smoking status of the subjects. Stratification was performed for age, sex, rural-urban distribution and smoking, the first three not being shown in the table.

\begin{tabular}{|c|c|c|c|c|c|}
\hline \multirow{2}{*}{ Smoking status } & \multicolumn{5}{|c|}{ Wall materiala } \\
\hline & A & B & C & $\mathrm{D}$ & $E$ \\
\hline \multicolumn{6}{|l|}{ Nonsmoker } \\
\hline $\begin{array}{l}\text { Cases } \\
\text { Referents }\end{array}$ & $\begin{array}{r}31 \\
182\end{array}$ & $\begin{array}{r}3 \\
29\end{array}$ & $\begin{array}{l}1 \\
4\end{array}$ & $\begin{array}{r}1 \\
12\end{array}$ & $\begin{array}{l}1 \\
4\end{array}$ \\
\hline \multicolumn{6}{|l|}{ Passive/occasional smoker } \\
\hline $\begin{array}{l}\text { Cases } \\
\text { Referents }\end{array}$ & $\begin{array}{r}18 \\
100\end{array}$ & $\begin{array}{r}6 \\
26\end{array}$ & $\begin{array}{l}0 \\
3\end{array}$ & $\begin{array}{l}0 \\
9\end{array}$ & $\begin{array}{l}1 \\
2\end{array}$ \\
\hline \multicolumn{6}{|l|}{ Regular smoker } \\
\hline $\begin{array}{l}\text { Cases } \\
\text { Referents }\end{array}$ & $\begin{array}{l}55 \\
66 \\
\end{array}$ & $\begin{array}{l}15 \\
15 \\
\end{array}$ & $\begin{array}{l}5 \\
1 \\
\end{array}$ & $\begin{array}{r}12 \\
4 \\
\end{array}$ & $\begin{array}{l}3 \\
0 \\
\end{array}$ \\
\hline \multicolumn{6}{|l|}{ Total } \\
\hline $\begin{array}{l}\text { Cases } \\
\text { Referents }\end{array}$ & $\begin{array}{r}104 \\
348\end{array}$ & $\begin{array}{l}24 \\
70\end{array}$ & $\begin{array}{l}6 \\
8\end{array}$ & $\begin{array}{l}13 \\
25\end{array}$ & $\begin{array}{l}5 \\
6\end{array}$ \\
\hline Crude rate ratio & 1.0 & 1.2 & 2.5 & 1.7 & 2.8 \\
\hline $\begin{array}{l}\text { Mantel-Haenszel rate ratio } \\
90 \% \text { confidence interval }\end{array}$ & 1.0 & $\begin{array}{c}1.1 \\
0.7-1.8\end{array}$ & $\begin{array}{c}2.0 \\
0.5-7.7\end{array}$ & $\begin{array}{c}1.4 \\
0.6-3.3\end{array}$ & $\begin{array}{c}3.9 \\
1.2-12.6\end{array}$ \\
\hline \multicolumn{6}{|c|}{ Mantel extension chi-square: 2.47} \\
\hline & \multicolumn{2}{|c|}{$A+B$} & \multicolumn{3}{|c|}{$C+D+E$} \\
\hline \multicolumn{6}{|l|}{ Total } \\
\hline $\begin{array}{l}\text { Cases } \\
\text { Referents }\end{array}$ & \multicolumn{2}{|c|}{$\begin{array}{l}128 \\
418\end{array}$} & \multicolumn{3}{|c|}{$\begin{array}{l}24 \\
39\end{array}$} \\
\hline Crude rate ratio & \multicolumn{2}{|c|}{1.0} & \multicolumn{3}{|c|}{2.0} \\
\hline $\begin{array}{l}\text { Mantel-Haenszel rate ratio } \\
90 \% \text { confidence interval }\end{array}$ & \multicolumn{2}{|c|}{1.0} & \multicolumn{3}{|c|}{$\begin{array}{c}2.0 \\
1.1-3.7\end{array}$} \\
\hline
\end{tabular}

a See table 1 for an explanation of the wall materials.

Table 6. Lung cancer cases and the referents according to the measured levels of radon daughter exposure and the location (rural-urban) of residency. Stratification by age, sex, and smok ing characteristics is not shown.

\begin{tabular}{|c|c|c|c|}
\hline \multirow[t]{2}{*}{ Area } & \multicolumn{3}{|c|}{$\begin{array}{c}\text { Radon daughter level } \\
\left(\mathrm{Bq} / \mathrm{m}^{3} \mathrm{EER}^{\mathrm{a}}\right)\end{array}$} \\
\hline & $<50$ & $50-149$ & $>150$ \\
\hline \multicolumn{4}{|l|}{ Rural } \\
\hline $\begin{array}{l}\text { Cases } \\
\text { Referents }\end{array}$ & $\begin{array}{l}34 \\
78\end{array}$ & $\begin{array}{l}29 \\
59 \\
59\end{array}$ & $\begin{array}{r}9 \\
15 \\
\cdots\end{array}$ \\
\hline Crude rate ratio & 1.0 & 1.1 & 1.4 \\
\hline $\begin{array}{l}\text { Mantel-Haenszel rate ratio } \\
90 \% \text { confidence interval }\end{array}$ & 1.0 & $\begin{array}{c}0.97 \\
0.6-1.7 \\
\end{array}$ & $\begin{array}{c}1.4 \\
0.6-3.2 \\
\end{array}$ \\
\hline \multicolumn{4}{|l|}{ Urban } \\
\hline $\begin{array}{l}\text { Cases } \\
\text { Referents }\end{array}$ & $\begin{array}{l}34 \\
41\end{array}$ & $\begin{array}{l}16 \\
34\end{array}$ & $\begin{array}{r}6 \\
15\end{array}$ \\
\hline Crude rate ratio & 1.0 & 0.6 & 0.5 \\
\hline $\begin{array}{l}\text { Mantel-Haenszel rate ratio } \\
90 \% \text { confidence interval }\end{array}$ & 1.0 & $\begin{array}{c}0.6 \\
0.3-1.2\end{array}$ & $\begin{array}{c}0.8 \\
0.2-3.0\end{array}$ \\
\hline
\end{tabular}

a See footnote a of table 1 for a definition of EER.

Finally, when the material was analyzed only with regard to the effect of passive smoking and smoking irrespective of radon exposure, the overall crude rate ratio was 1.2 for passive and 4.8 for active smoking, the latter category also including occasional smoking. The corresponding Mantel-Haenszel rate ratios were 0.9 and 5.6, respectively; therefore the effect of passive smoking was weak in this material. Very similar rate ratios were obtained by stratification according to the categories of assumed radon daughter exposure.

\section{Discussion}

In the studies undertaken with regard to radon in homes and lung cancer, there has always been much uncertainty about actual exposure. There have either been assumptions about exposure levels with regard to the building material and character of the houses where the subjects lived or the measurements have been undertaken with various techniques, eg, alpha-sensitive film, as also used in this study. This method of measurement may be criticized for not being particularly precise, but, in the present study, it was the only alternative for practical and economic reasons. Furthermore, we had to rely on the houseowner's cooperation for hanging up the strips of film, and some may not have followed the instructions in this respect.

Inadequate exposure classification should not lead to a finding of increased risk however; conversely it would result in the masking of an effect. Similarly, if only particular histopathological types of lung cancer are related to radon daughter exposure, a broad case entity (ICD-8 162-163), as in this study, would tend to make the risk estimates conservative. The present study may be criticized in this respect as having too 
Table 7. Lung cancer cases and the referents among the passive and occasional smokers according to exposure categories and sex. Stratification by urban-rural distribution and age is not shown.

\begin{tabular}{|c|c|c|c|c|}
\hline \multirow{2}{*}{ Sex } & \multicolumn{4}{|c|}{ Exposure category ${ }^{a}$} \\
\hline & 0 & 1 & 2 & $1+2$ \\
\hline \multicolumn{5}{|l|}{ Male } \\
\hline \multicolumn{5}{|l|}{ Passive smokers } \\
\hline $\begin{array}{l}\text { Cases } \\
\text { Referents }\end{array}$ & $\overline{13}$ & $\begin{array}{l}3 \\
5\end{array}$ & $\begin{array}{l}1 \\
8\end{array}$ & $\begin{array}{r}4 \\
13\end{array}$ \\
\hline \multicolumn{5}{|l|}{ Occasional smokers } \\
\hline $\begin{array}{l}\text { Cases } \\
\text { Referents }\end{array}$ & $\begin{array}{r}2 \\
16\end{array}$ & $\begin{array}{r}1 \\
10\end{array}$ & $\begin{array}{l}3 \\
9\end{array}$ & $\begin{array}{r}4 \\
19\end{array}$ \\
\hline \multicolumn{5}{|l|}{ Female } \\
\hline \multicolumn{5}{|l|}{ Passive smokers } \\
\hline $\begin{array}{l}\text { Cases } \\
\text { Referents }\end{array}$ & $\begin{array}{r}4 \\
27\end{array}$ & $\begin{array}{r}5 \\
24\end{array}$ & $\begin{array}{r}6 \\
24\end{array}$ & $\begin{array}{r}1 \\
48\end{array}$ \\
\hline \multicolumn{5}{|l|}{ Occasional smokers } \\
\hline $\begin{array}{l}\text { Cases } \\
\text { Referents }\end{array}$ & $\overline{1}$ & $\overline{2}$ & $\overline{1}$ & $\overline{3}$ \\
\hline \multicolumn{5}{|l|}{ Total } \\
\hline $\begin{array}{l}\text { Cases } \\
\text { Referents }\end{array}$ & $\begin{array}{r}6 \\
57 \\
\end{array}$ & $\begin{array}{r}9 \\
41 \\
\end{array}$ & $\begin{array}{l}10 \\
42 \\
\end{array}$ & $\begin{array}{l}19 \\
83 \\
\end{array}$ \\
\hline Crude rate ratio & 1.0 & 2.1 & 2.3 & 2.2 \\
\hline $\begin{array}{l}\text { Mantel-Haenszel rate ratio } \\
90 \% \text { confidence interval }\end{array}$ & 1.0 & $0.8-4.5$ & $1.3^{2.9}-6.6$ & $1.2^{2.7}-6.1$ \\
\hline Mantel extension chi-square: 4.73 & & & & \\
\hline
\end{tabular}

a See footnote $\mathrm{c}$ of table 1 for an explanation of the exposure categories.

broad a case entity, but it was chosen to be in agreement with that used in our previous study (11) and to avoid both additional costs and a discussion about selection problems.

In view of the fact that radon daughter exposure in mines is a clear risk factor for lung cancer, the hypothesis of the present study was strongly suggestive of such an effect also from indoor exposure. However, the results obtained in the various analyses of this material did not always clearly support a lung cancer effect, especially not with regard to the urban sector of the population studied. Is is noteworthy that the differences between the urban and the rural sectors of the study were obtained with regard to both the categories of assumed exposure and the measurements. There seems to be no immediate explanation at hand, eg, the possibility of simple misclassification or poor measurements, nor can any good explanation be offered for the unexpected pattern of the rate ratios over the categories of exposure. The small numbers in the reference category for the urban sector of this study are obviously one weakness in this context, especially since there are also possibilities that a weak risk factor (radon daughter exposure) was obscured by the presence of a stronger one (smoking) due to remaining confounding and/or random variation (5). This possibility is also supported by the fact that the smoking categories were rather crude in this study. (The evaluation of smoking as such with regard to lung cancer was of little interest in this study since some of the diagnoses of the referents were smoking-related, and therefore the effect seen from smoking would be an underestimation.)

Since it is necessary for the contrast between exposed and unexposed individuals to be clear before an effect of a particular exposure can be distinguished, it is obvious that studies of lung cancer and indoor radon are inherently difficult and insensitive, since no one is unexposed. Even if measurements might provide a helpful basis for the assessment of exposure, there is not necessarily any particularly good agreement between current measurements and the actual exposure of the subjects over many decades. Therefore, in addition to measurements, it is also probably sensible to consider wall material, type of house, ground conditions, and other knowledge about the background radiation of an area, as has been done in this study. However, a classification of exposure on such a basis may also fail, the result being an insensitive study.

Somewhat surprisingly, the classification by wall material agreed better with the measured levels of radon daughters than the more sophisticated attempt to construct exposure categories with as clear a contrast as possible. (See table 1.) Therefore, the increased rate ratios obtained in relation to wall materials, implying elevated indoor radon daughter levels, seemed to strengthen the assumption of a relation between radon in homes and lung cancer.

In a rural population, it is probably more likely that the women especially have spent most of their indoor time at home, whereas the situation in this respect may be different for an urban population. However, also 
in urban areas, women of the generation involved in this study were likely to have spent most of their indoor time at home. It seems reasonable therefore to put more emphasis on the findings that relate to the rural population and to the women in the population under study. Thus the overall interpretation of the analyses of this study would be that indoor radon daughter exposure is likely to have exerted an effect on lung cancer mortality, even if the urban sector of the population showed a risk pattern which is inconsistent with such an effect and in spite of the fact that no definite explanation can be given for the deviating findings in this respect. The appearance of only cases in the exposure categories with the highest measurements is remarkable, however, and strongly supportive of an effect even if such an effect did not formally appear in the calculated risk estimates. The rather clear effect seen among the passive and occasional smokers and among the passive smokers alone suggests that future studies of passive smoking should also take radon daughter exposure into account. Radon daughters tend to attach to smoke particles (7), and there is a possibility for increased exposure to radon daughters in the presence of environmental tobacco smoke and/or an interaction may take place on the cellular level.

Finally, it may be noted that the finding obtained for the rural population in this study reproduced the results of our previous studies that were restricted to rural populations $(3,11)$. If the findings from these studies and other investigations referred to in the introduction, as well as our present data, are taken into account, it seems as if the lung cancer risk could approximately double due to an elevation above the unavoidable background of indoor radon daughter levels. This assumption also implies that indoor radon daughter exposure at unavoidable levels might play some role in the etiology of lung cancer. Further studies are known to be under way in several countries and may help to achieve a definite evaluation of the lung cancer risk from indoor radon.

\section{Acknowledgments}

We thank Ms $\mathrm{H}$ Noorlind-Brage, Mr M Fredriksson, and the local health authorities of the communes involved for their assistance.

The study had limited economic support from the Swedish Cancer Society, the County Council of Östergötland, and some of the communes involved.

\section{References}

1. Akerblom G, Wilson C. Radon - Geological aspects of an environmental problem. Sveriges geologiska undersökningar, Uppsala (Sweden) 1982. (Rapporter och meddelanden $\mathrm{nr} 30$ ).

2. Axelson $\mathrm{O}$. Elucidation of some epidemiologic principles. Scand J Work Environ Health 9 (1983) $231-240$.
3. Axelson $\mathrm{O}$, Edling $\mathrm{C}$, Kling $\mathrm{H}$. Lung cancer and residency - A case-referent study on the possible impact of exposure to radon and its daughters in dwellings. Scand J Work Environ Health 5 (1979) 10-15.

4. Axelson $\mathrm{O}$, Edling $\mathrm{C}$, Kling $\mathrm{H}$, Andersson $\mathrm{L}$, Ringner A. Lung-cancer and radon in dwellings. Lancet 2 (1981) 995-996.

5. Axelson O, Steenland K. Indirect methods of assessing the effects of tobacco use in occupational studies. Am $J$ Ind Med 13 (1988) 105-118.

6. Bean JA, Isacson P, Hahne RMA, Kohler J. Drinking water and cancer incidence in Iowa. Am J Epidemiol 116 (1982) 924--932.

7. Bergman $\mathrm{H}$, Edling $\mathrm{C}$, Axelson $\mathrm{O}$. Indoor radon daughter concentrations and passive smoking. Environ Int 12 (1986) 17-19.

8. Damber L, Larsson L-G. Lung cancer in males and type of dwelling: An epidemiological pilot study. Acta Radiol Oncol 26 (1987) 211-215.

9. Dousset M, Jammet $\mathbf{H}$. Comparaison de la mortalite par cancer dans le Limousin et le Poitou-Charentes. Radioprotection 20 (1985) $61-67$.

10. Edling C, Comba P, Axelson O, Flodin U. Effects of low-dose radiation - A correlation study. Scand J Work Environ Health 8 (1982): suppl 1, 59-64.

11. Edling $\mathrm{C}$, Kling $\mathrm{H}$, Axelson $\mathrm{O}$. Radon in homes - A possible cause of lung cancer. Scand J Work Environ Health 10 (1984) 25-34.

12. Fleischer RL. A possible association between lung cancer and phosphate mining and processing. Health Phys 41 (1981) $171-175$.

13. Forastiere $\mathbf{F}$, Valesini $\mathrm{S}$, Arca $\mathrm{M}$, Magliola ME, Michelozzi $\mathrm{P}$, Tasco $\mathrm{C}$. Lung cancer and natural radiation in an Italian province. Sci Total Environ 45 (1985) $519-526$.

14. Hess CT, Weiffenbach CV, Norton SA. Environmental radon and cancer correlations in Maine. Health Phys 45 (1983) 339-348.

15. Hofmann $\mathrm{W}$, Katz $\mathrm{R}$, Zhang $\mathrm{C}$. Lung cancer incidence in a Chinese high background area - Epidemiological results and theoretical interpretation. Sci Total Environ 45 (1985) $527-534$.

16. Lanes SF. Lung cancer and environmental radon exposure: A case-control study. Diss Abstr Int B 43 (1983) 2787B-2788B.

17. Lanes SF, Talbott E, Radford E. Lung cancer and environmental radon. Am J Epidemiol 116 (1982) 565.

18. Mantel N. Chi-square tests with one degree of freedom: Extensions of the Mantel-Haenszel procedure. Am Stat Assoc J 58 (1963) 690-700.

19. Mantel N, Haenszel W. Statistical aspects of the analysis of the data from retrospective studies of disease. $\mathbf{J}$ Natl Cancer Inst 23 (1959) 719-748.

20. Miettinen OS. Components of the crude risk ratio. Am J Epidemiol 96 (1972) 168-172.

21. Miettinen OS. Standardization of risk ratios. Am J Epidemiol 96 (1972) 383-388.

22. Miettinen OS. Estimability and estimation in case-referent studies. Am J Epidemiol 103 (1976) 226-..235.

23. Pershagen G, Damber L, Falk R. Exposure to radon in dwellings and lung cancer: A pilot study. In: Berglund B, Lindvall T, Sundell J, ed. Indoor air: Radon, passive smoking, particulates and housing epidemiology 2 . Swedish Council for Building Research, Stockholm 1984, pp $73-78$.

24. Simpson SG, Comstock GW. Lung cancer and housing characteristics. Arch Environ Health 38 (1983) 248-251.

25. Svensson C, Eklund G, Pershagen G. Indoor exposure to radon from the ground and bronchial cancer in women. Int Arch Occup Environ Health 59 (1987) $123-131$.

Received for publication: 23 March 1988 